\title{
Crowdfunding and museums: A field trip exemplar in the UK
}

This article sketches a project designed for an undergraduate course dealing with social contexts of entrepreneurship. The learning activity asks students to devise a reward-based crowdfunding campaign for a museum. The project relies on a field trip to a museum where students gather a better understanding of fiscal and brand visibility challenges currently unsettling these types of organizations. The project draws on intra and extra classroom activities that integrate innovative trends in entrepreneurship teaching, bridging theory and real-life applications. The exercise motivates students to design solutions, develop collaborations and co-create value processes with the organization and diverse actors. The activities span over a 4-week period with tasks prior, during and after the museum fieldtrip, culminating with a presentation of a crowdfunding campaign. The pedagogical value of this exercise relates to students co-creating entrepreneurial action with a client/entrepreneurial organization within a resource constrained environment, which motivates the design of innovative crowdfunding campaigns and empathizes with the entrepreneurial demands placed on cultural organizations. Cultural, social and creative problem-solving competencies for working in international and multidisciplinary teams around crowdfunding can be expected as outcomes. This exercise can be advantageous for courses dealing with the multifaceted dynamics of social contexts of entrepreneurship.

Keywords: Entrepreneurship, Crowdfunding, Museums, Field Trip, International classroom 


\section{Overview}

This project was designed to immerse students in a context where they can deepen their understanding of entrepreneurship related to real-life challenges. A challenge in teaching entrepreneurship is to connect theory and practice (Fayolle, 2013; Turner \& Gianiodis, 2018). Entrepreneurship instructors are called to develop experiences that embody teamwork and creativity coupled with practical activities that advance entrepreneurial learning and competences (Neck \& Corbett, 2018). Accordingly, we designed a field trip activity for undergraduate students connected to crowdfunding a specific project (Mollick, 2014) for a cultural organization.

In this exercise, teams of students engage on the design of a crowdfunding campaign as a platform for the development of collaborations and entrepreneurial co-creation of value mechanisms (Burgelman \& Hitt, 2007) for a cultural organization. Co-creation relates to an innovative process for the generation or regeneration of value in a service or project (Chandler \& Wieland, 2010; Mele, Russo-Spena, \& Colurcio, 2010). It is a process by which a museum can enrich a crowdfunding project value by eliciting collaborations, suggestions and support from various stakeholders (i.e. teams of students, museum staff, strategic partnerships and the 'crowd') (Hui, Greenberg, \& Gerber, 2014; Josefy, Dean, Albert, \& Fitza, 2017). Students use the crowdfunding project as an entrepreneurial advantage to get maximum engagement with regional communities and key actors' endorsements. Additionally, the exercise helps students to level some of the challenges arising from an multidisciplinary and international entrepreneurship classroom, including divergent cultural expectations, interests, and communication styles (Cascio \& Shurygalio, 2003; Erez et al., 2013; Janssens \& Brett, 2006).

To address the abovementioned challenges, we were committed to offering concrete opportunities for students to enhance their cultural, social and creative problem-solving competencies (Leung, Maddux, Galinsky, \& Chiu, 2008). The building of competences 
involves blending acquired theoretical and practical knowledge to develop skills and performance within a particular context (Ferrés \& Piscitelli, 2012). Thus, in order to facilitate the development of these competencies, we devised a learning project that combined active participation both inside and outside the classroom combining tried-and-tested approaches (a fieldtrip), with novel entrepreneurial finance models (crowdfunding).

For the fieldtrip, we selected a local city museum in the Northwest region of the United Kingdom for several reasons. First, museums provide social and educational environments that are highly compatible with student field trips (Coffee, 2007; Decker, 2015, p. 3). Second, a museum setting is appropriate for entrepreneurial approaches since governments around the world have endorsed through public policy the notion that cultural institutions should operate more entrepreneurially due to fiscal setbacks, and economic uncertainties (Leventhal \& Zeylikovich, 2015, p. 95; Pickles, 2015). Accordingly, museums are increasingly considering new business models to enhance their commercial options (e.g., museum merchandising, gift shops, coffee shops, and service fees), social digital engagement, and funding sources (Kotler \& Kotler, 2000; Pickles, 2015; Sanders, 2012; Toepler, 2006). Finally, the community-based nature of museums can make them particularly well suited to crowdfunding initiatives (Riley-Huff, Herrera, Ivey, \& Harry, 2016) and innovative pedagogies for the twenty-first century learner (Xanthoudaki, 2015). Hence, to connect the crowdfunding literature and benefits of fieldtrips to academic material, we focused on museums as a cultural and social organization.

To link the fieldtrip to community based entrepreneurial experience, we asked students to identify how the museum might use crowdfunding to increase its online commercial presence, cultivate new audiences and partake in a new funding model for exclusive projects (Mollick \& Nanda, 2015). Because museums in various countries might be seeking different ways to become more 'entrepreneurial' (Gradén \& O’Dell, 2017), we anticipated that our culturally diverse and multidisciplinary classroom would find this 
crowdfunding exercise innovative and relevant even for countries other than the United Kingdom.

\section{Background: Field Trips and Crowdfunding}

The pedagogical value of field trips is well documented. Field trips are a shared social experience that provide students from diverse backgrounds the opportunity to go outside the classroom and explore theoretical perspectives, increase their interest in a specific topic and facilitate collective engagement in an authentic social setting (DeWitt \& Osborne, 2007; Greene, Kisida, \& Bowen, 2014). When a field trip is appropriately structured and planned (Falk, Moussouri, \& Coulson, 1998), it helps students to contextualize theoretical discussions in the classroom and observe 'real-world' practices that extend their academic understanding (DeWitt \& Storksdieck, 2008).

Crowdfunding - the practice of funding an idea or project by soliciting a wide range of potential monetary contributors via the Internet (Mollick, 2014) - is gaining attention as a legitimate entrepreneurship topic (McKenny, Allison, Ketchen, Short, \& Ireland, 2017; World Bank, 2013, p. 20) and is one of the newest entrepreneurial means for attaining funds and social engagement. Crowdfunding is malleable to fit different contexts. Both for-profit and non-profit organizations have managed successful crowdfunding campaigns to finance entrepreneurial projects or ideas. Table 1 shows a list of crowdfunding models and platforms.

- Insert table 1 about here -

For this activity, we have focused on reward-based crowdfunding because it is the standard model utilized in the creative and cultural industries (Mollick \& Nanda, 2015). A reward-based model offers funders various perks or pre-purchase products or services depending on selected funding levels (Thürridl \& Kamleitner, 2016; World Bank, 2013p. 20). These rewards may range from a 'Thank You' postcard to an array of recognition events or products (ibid). The challenge for individuals and organizations is that crowdfunding campaigns contain multiple components that need to be developed including: narratives, 
videos and rewards as well as a proactive social outreach to activate a project-based community (Hui et al., 2014; Josefy et al., 2017). Therefore, campaigns are labor and time intensive. Often, crowdfunding campaigns are managed by a team of invested members and volunteers, even if temporarily, to perform the work with efficiency and agility until the end of the campaign (Gerber \& Hui, 2013; Hobbs, Grigore, \& Molesworth, 2016; Hui et al., 2014). For this exercise, recent museum's reward-based crowdfunding campaigns in the UK are presented in table 2 .

- Insert table 2 about here -

Consistent with the crowdfunding literature, the instructors assisted students in recognizing that the outcome of a crowdfunding campaign is uncertain and sometimes risky in terms of achieving its financial goals (Mollick, 2014). However, we also noted to students that individuals and organizations continue to engage in crowdfunding because there is always a chance of success, including the aspiration to build a project-based community that is necessary for product and project promotion within a specified market (ibid).

\section{Learning about Social Capital and Trust in Crowdfunding}

This exercise engages student in activities that impact on entrepreneurial learning through the identification of opportunities as well as sense-making in organizations (Harrison \& Leitch, 2005; Wang \& Chugh, 2014; Young \& Sexton, 1997). To achieve this, instructors discuss with students the museum organization's disposition to learn how to co-create value while exploring and exploiting new ways of funding impending projects and initiatives. To support this approach, and since crowdfunding elicits an array of social connotations, we considered appropriate to discuss other relevant theories related to reward-based crowdfunding dynamics (Table 3, Week 1).

First, we highlight the importance for creators to develop networks and social capital during single and serial crowdfunding campaigns (Butticè, Colombo, \& Wright, 2017; 
Colombo, Franzoni, \& Rossi-Lamastra, 2015; Skirnevskiy, Bendig, \& Brettel, 2017). Lecture debates included questions such as: who is the crowd? Based on such literature students identified the initial impact of internal and external social capital in crowdfunding. Family and friends are considered 'external' social capital because they represent networks outside of crowdfunding platforms (Agrawal, Catalini, \& Goldfarb, 2015; Kuppuswamy \& Bayus, 2015) whereas internal social capital refers to the crowdfunding participants and communities, formed inside a crowdfunding platform (Colombo et al., 2015; Skirnevskiy et al., 2017). Students appreciated that networks are shaped by crowdfunding efforts, which can benefit future campaigns and beyond (Colombo et al., 2015; Kuppuswamy \& Bayus, 2015; Mollick \& Nanda, 2015; Ordanini et al., 2011).

Second, a key concept discussed with students revolved around the development of trust. Discussions about theories of trust were incorporated to reflect funders expectations and evaluation of creators' trustworthiness to coordinate campaigns and complete projects as promised (Courtney, Dutta, \& Li, 2017). This notion is particularly important in crowdfunding since compelling success factors such as campaign video and narrative can create perceptions regarding the creator's trustworthiness (Gerber \& Hui, 2013). Hence, using Mayer, Davis and Schoorman (1995) trust model, the instructors guided students to examine examples of crowdfunding creators' demonstration of trust dimensions, namely competence (ability), benevolence and integrity (Mayer et al, 1995) to attract funders contributions and participation.

Finally, the concept of 'swift trust' (Meyerson, Weick, \& Kramer, 1996) was introduced because of the temporality of crowdfunding student-led teams. This unique form of trust has been observed to unfold in international, temporal and virtual teams in organizations around the world (Crisp \& Jarvenpaa, 2013). Often, these individuals are not familiar with the new temporal co-workers. Yet, they can synchronize skills and efforts to achieve swiftly a high-quality product (e.g. a video, a campaign). We emphasized to students 
that this exercise would help them develop practical knowledge sharing and collaborative skills while dealing with a time-constrained project with peers (e.g. international exchange students, or from other programs of study) and an organization they do not necessarily know (Crisp \& Jarvenpaa, 2013). 'Swift trust' resonates with the temporality of multidisciplinary and goal oriented performances in this exercise.

\section{Museums as a context for Entrepreneurial Learning}

Entrepreneurial learning also calls for a contextual appreciation of entrepreneurship (Wang \& Chugh, 2014). Entrepreneurship is relevant for cultural organizations, such as museums, because it promotes innovation and risk-taking strategic choices that might strengthen the delivery of new services (Morris \& Jones, 1999; Thompson, 2003). An emerging strategic choice for museums is cultivating an online presence and younger audiences through technology and social digital engagement (Rovner, Loeb, \& Vogel, 2013, pp. 16, 25). This approach enables younger audiences to become educated in the museum's offerings while expanding the museum's overall visitor base (Decker, 2015, p. 1; Falk \& Sheppard, 2006, p. 90; Rovner et al., 2013). Museums welcome diverse audiences (Gradén \& O'Dell, 2017), and particularly younger audiences' active involvement since visitors' statistics are one of the quantifiable measurements that justify a museum's presence and existence (Clark \& Stewart, 2012). Therefore, this activity explores entrepreneurship and crowdfunding as concepts which can leverage the city museum's visitor statistics and support thus providing a context for entrepreneurial learning.

In table 3, we have attempted to design a comprehensive schedule for our learning exercise. While this exercise could work well in a number of classrooms, we encourage instructors to adjust and modify our guidelines to effectively meet the requirements of their own context, and course scheduling. In this regard, we have also revise this exercise every year to meet the constantly evolving dynamics of entrepreneurial finance. In contexts where 
discipline diversity and multicultural backgrounds are minimal, instructors can allocate students to groups randomly.

- Insert table 3 about here-

\section{How to run the Museum Fieldtrip and Crowdfunding exercise}

\section{The Field Trip Activity}

The instructors designed the activity for a maximum of 80 students. In the activity, instructors assigned students into three classes of approximately 27 students each. Each class comprised five groups ( 5 to 6 students each). Based on registration, the class had a high enrollment of international exchange students. Additionally, since this is a popular elective, a number of students outside entrepreneurship majors also enrolled in the class. Therefore, we decided on an international and multidisciplinary perspective to facilitate the simulation of 'real world' global and temporary teams trying to solve a regional challenge. Accordingly, instructors allocated students to groups to ensure discipline and cultural diversity. Instructors also met with groups to discuss the progress of their projects, and groups' dynamics throughout the entire 4 weeks. Two instructors organized the activity: one instructor/assistant professor and one graduate associate lecturer per class. Table 3 details the 4 -week interval implementation schedule, and Table 4 lists suggested reading materials.

- $\quad$ insert table 4 about here-

\section{Advance Preparation: Academic Lecture and Student Preparation}

Before the field trip, the instructors delivered a lecture on crowdfunding models, associated theories, and museum campaign examples (Tables 1, 2, and 3). A successful crowdfunding entrepreneur and/or a museum director/employee were also invited as guest speakers. At the end of the lecture, the instructors distributed the first handout to each group (Table 5). Tasks 1 and 2 allowed students to reflect on the academic material before and 
during the field trip.

- Insert table 5 about here-

\section{The Field Trip: A Local Museum}

Each class arrived at the selected museum at a specific date and time during museum opening hours (Table 3). Before the students perused the facilities, the instructors provided a brief information session describing the museum's operations and exhibits. The instructors remained available to make classroom connections in situ. At the end of the trip, the instructors distributed a second handout (Table 6). Tasks 3 and 4 focused on understanding the multifaceted dimensions of crowdfunding and entrepreneurship.

- Insert table 6 about here-

\section{Classroom Presentations: Crowdfunding Campaign}

In weeks 2 and 3, the groups staged their presentations on the university premises (Table 3). The presentations comprise of an entire project-based crowdfunding campaign highlighting choice project, videos, rewards, social media strategy and community engagement including outreach support emerging from collaborations with local businesses and government entities. Students made their presentations as if they were addressing potential supporters. Table 7 shows the required components of the presentation that are evaluated and can be adapted to percentage or letter grade marking schemes (see table 8 for evaluation criteria).

- Insert table 7 about here-

- Insert table 8 about here-

\section{Debriefing and Discussion}

In week 4, the instructors lead a discussion and debriefing (Table 3) to allow students to reflect on what they learned throughout the project. The questions asked by instructors are listed in Table 9.

- Insert table 9 about here- 
During the debriefing, various applications and discussions transpired, including the following:

\section{Finding Equilibrium between Theory and Praxis}

During and after the field trip, the instructors continued to educate students on the equilibrium between theory and praxis by developing guiding discussions during workshop times in preparation to their fieldtrip and project development. Observing how each group explored the aptitudes of individual members was remarkable. For instance, based on theoretical perspectives, teams identified group members who could easily translate the concept into praxis. This knowledge-sharing mechanism between peers allowed groups to gain further insight into this equilibrium. In this respect, students were able to recognized that a museum could act as a steward of local history and culture while aligning its mission of education and heritage conservation with the interests of the communities (i.e., 'principals') they aim to serve (Davis, Schoorman, \& Donaldson, 1997) as well as serve as a milieu for entrepreneurial engagement.

Most students indicated that the field trip allowed them to combine theory and praxis. Accordingly, the project activities were designed to deliver an optimal combination of both while opening new avenues for students to consider collaborations and co-creation of value processes in the context of crowdfunding. Accordingly, during the discussion session, we discovered that this groundwork helped students to make strategic choices regarding their projects, and some groups added supplementary theories to their reports to better support their own entrepreneurial approach to crowdfunding. This observation seems accurate to describe the pedagogical relevance of this exercise, since teamwork, creativity and communication coupled with knowledge and practical activities can advance entrepreneurial learning, competences (Neck \& Corbett, 2018) and co-creation of entrepreneurial action.

\section{The Museum and Crowdfunding}


The social context of entrepreneurship often includes community, social engagement, and financial considerations (Peredo \& Chrisman, 2006), which the crowdfunding process reflects accordingly. As we supervised the students' preparations, students indicated that the lecture and the pre-field trip preparation primed them to ask relevant questions of the museum organization's staff, local business owners, and government entities.

Students acknowledged that during the interviews, they prompted staff to discuss the museum's online presence and digital engagement. As expected, students felt that crowdfunding was an ideal opportunity for the museum to test and practice various forms of social digital engagement. These conversations assisted students in planning systematic campaigns' storylines and communications.

Due to the nature and design of crowdfunding campaigns, students had to generate ideas for a project-focused narrative and rewards. Noticeably, students thoroughly enjoyed setting original campaign themes and pitches in motion, particularly 'A Night at the Museum,' where local artists and catering businesses would collaborate to entertain visitors on the museum premises, and 'A medieval faire', emphasizing collaboration between the museum, universities and local city councils to celebrate regional medieval festivals. Every proposal included a factual cost analysis, and some campaigns included technology-based interactive programs to attract and educate younger audiences within the museum's facilities.

The instructors steered the groups to review potential market segments and opportunities for collaboration with key community actors and businesses. The students also organized different groups of volunteers to help the museum fulfill the labor-intensive demands of crowdfunding campaigns. Volunteer groups included students interested in building their practical skills (i.e. students who want to improve their web design or marketing skills), campus arts associations as museums partners, local school groups, and senior citizens associations. Furthermore, all the proposed campaigns prioritized the visitor 
experience by repositioning the current museum's focus on entertainment alongside collaborations with local businesses (Kotler \& Kotler, 2000).

\section{Culturally Diverse and Multidisciplinary Groups}

A collaborative approach by students may exhibit complex multilevel structures (Bennis \& Biederman, 2007, p. 5; Huxham \& Vangen, 2005, pp. 136, 157) especially if group are assembled to complete a project within a specified time (Crisp \& Jarvenpaa, 2013). Crowdfunding campaigns usually require a specific time frame from pre-planning to completion. Hence, we intentionally organized diverse groups to add a real-life perspective of working in temporal international teams trying to swiftly accomplish a labor-intensive project. Our aim was to optimistically advance students' cultural, social and creative problem-solving competencies that often lead to innovation advantages, (Chua, Morris, \& Mor, 2012) even when working in temporary teams. This approach allowed instructors to facilitate the development of students' learning experiences (Neck \& Corbett, 2018) in a unique setting. During the debriefing, we asked the students to share their experiences related to working with allocated groups. Students acknowledge that complex discussions occurred within their groups because of cross-major proficiencies and cultural diversity.

Students noted that some group dynamics were strained initially. Nonetheless, to their amazement, diversity and multidisciplinary paradigms were welcomed over time, as conversations, prompted by 'swift trust', enhanced their ability to work with team members with whom they had never previously interacted. Additionally, students indicated that their learning scope expanded as a result of reviewing other student-led campaigns.

\section{Conclusion}

This project allows educators to teach students about the social context of entrepreneurship through a field trip and a crowdfunding activity. The field trip experience 
can increase students' consciousness of the cultural role played by organizations, such as museums, in communities and the entrepreneurial options that can influence their sustainability. The core pedagogical contribution of this exercise is that it allows instructors and students to review entrepreneurial collaborations and co-creation of value processes as advantages for attracting potential funders while spawning the powerful role of sharedinterest communities in this context. Students co-create entrepreneurial action with a museum by considering a resource constrained environment, which motivates the design of innovative crowdfunding campaigns and allows students to empathize with the entrepreneurial demands of cultural organizations. Such approach can benefit cultural organizations while allowing students to reflect on the value of these institutions and their overall impact on communities. Instructors can expect a positive classroom experience due to the opportunity to integrate academic material and praxis in a social context. Because this project was deployed in an international classroom, students engaged in dynamics of diverse academic disciplines and multicultural backgrounds. Students noted that this activity produced rich conversations and problem-solving negotiations with the aim of devising a cohesive crowdfunding campaign. This learning innovation exercise can be applied in other contexts where museums or similar organizations aim to develop new initiatives that could be crowdfunded to enhance the organizations' visibility and connection to its surrounding community.

\section{References}

Agrawal, A., Catalini, C., \& Goldfarb, A. (2015). Crowdfunding: Geography, social networks, and the timing of investment decisions. Journal of Economics \& Management Strategy, 24(2), 253-274.

Bennis, W., \& Biederman, P. . (2007). Organizing Genius: The secrets of creative collaboration. Reading, Massachusetts: Addison-Wesley.

Burgelman, R. A., \& Hitt, M. A. (2007). Entrepreneurial actions, innovation, and 
appropriability. Strategic Entrepreneurship Journal, 1(3-4), 349-352.

Butticè, V., Colombo, M. G., \& Wright, M. (2017). Serial crowdfunding, social capital, and project success. Entrepreneurship Theory and Practice, 41(2), 183-207.

Cascio, W. F., \& Shurygalio, S. (2003). E-leadership and virtual teams. Organizational Dynamics, 31, 362-376.

Chandler, J. R. D., \& Wieland, H. (2010). Embeded relationships: implications for networks, innovation and ecosystems. Journal of Business Market Management, 4(4), 199-215.

Chua, R. Y., Morris, M. W., \& Mor, S. (2012). Collaborating across cultures: Cultural metacognition and affect-based trust in creative collaboration. Organizational Behavior and Human Decision Processes, 118(2), 116-131. http://doi.org/https://doi.org/10.1016/j.obhdp.2012.03.009

Clark, T., \& Stewart, J. (2012). Teaching social entrepreneurship: Arts management with a community engaged perspective. Journal of Entrepreneurship Education, 15(1).

Coffee, K. (2007). Audience Research and the Museum Experience as Social Practice. Museum Management and Curatorship, 22(4), 377-389. http://doi.org/10.1080/09647770701757732

Colombo, M. G., Franzoni, C., \& Rossi-Lamastra, C. (2015). Internal Social Capital and the Attraction of Early Contributions in Crowdfunding. Entrepreneurship Theory and Practice, 39(1), 75-100. http://doi.org/10.1111/etap.12118

Courtney, C., Dutta, S., \& Li, Y. (2017). Resolving information asymmetry: Signaling, endorsement, and crowdfunding success. Entrepreneurship Theory and Practice, 41(2), $265-290$.

Crisp, C. B., \& Jarvenpaa, S. L. (2013). Swift trust in global virtual teams: Trusting beliefs and normative actions. Journal of Personnel Psychology, 12(1), 45-56.

Davis, J. H., Schoorman, F. D., \& Donaldson, L. (1997). Toward a Stewardship Theory of Management. Academy of Management Review, 22(1), 20-47. 
Decker, J. ed. (2015). Fundraising and Strategy Planning: Innovative Approaches for Museums. New York: Rowman \& Littlefield.

DeWitt, J., \& Osborne, J. (2007). Supporting teachers on science-focused school trips: Towards an integrated framework of theory and practice. International Journal of Science Education, 29, 685-710.

DeWitt, J., \& Storksdieck, M. (2008). A Short Review of School Field Trips: Key Findings from the Past and Implications for the Future. Visitor Studies, 11(2), 181-197. http://doi.org/10.1080/10645570802355562

Erez, M., Lisak, A., Harush, R., Glikson, E., Nouri, R., \& Shokef, E. (2013). Going Global: Developing Management Students' Cultural Intelligence and Global Identity in Culturally Diverse Virtual Teams. Academy of Management Learning \& Education, 12(3), 330-355.

Falk, J. H., Moussouri, T., \& Coulson, D. (1998). The effect of visitors' agendas on museum learning. Curator, 41, 107-120.

Falk, J. H., \& Sheppard, B. . (2006). Thriving in the knowledge age: New business models for museums and other cultural institutions. Lanhan, Maryland: Altamira Press.

Fayolle, A. (2013). Personal views on the future of entrepreneurship education. Entrepreneurship \& Regional Development, 25(7-8), 692-701. http://doi.org/10.1080/08985626.2013.821318

Ferrés, J., \& Piscitelli, A. (2012). Media competence. Articulated proposal of dimensions and indicators. Comunicar, 19(38), 75-81.

Gerber, E. M., \& Hui, J. (2013). Crowdfunding: Motivations and Deterrents for Participation. ACM Transactions on Computer-Human Interaction, 20(6), 1-32. http://doi.org/10.1145/2530540

Gradén, L., \& O’Dell, T. (2017). Museums and Heritage Collections in the Cultural Economy: The Challenge of Addressing Wider Audiences and Local Communities. 
Museum International, 68(3-4), 48-67. http://doi.org/10.1111/muse.12135

Greene, J. P., Kisida, B., \& Bowen, D. . (2014). The educational value of fieldtrips. EducationNext, 14(1), 78-86.

Harrison, R. T., \& Leitch, C. M. (2005). Entrepreneurial learning: Researching the interface between learning and the entrepreneurial context. Entrepreneurship Theory and Practice, 29(4), 351-371.

Hobbs, J., Grigore, G., \& Molesworth, M. (2016). Success in the management of crowdfunding projects in the creative industries. Internet Research, 26(1), 146-166. http://doi.org/10.1108/IntR-08-2014-0202

Hui, J. S., Greenberg, M. D., \& Gerber, E. M. (2014). Understanding the role of community in crowdfunding work. In Proceedings of the 17th ACM Conference on Computer Supported Cooperative Work \& Social Computing, Baltimore, MD (pp. 62-74). New York, NY: ACM.

Huxham, C., \& Vangen, S. (2005). Managing to Collaborate: The theory and practice of collaborative advantage. London: Routledge.

Janssens, M., \& Brett, J. M. (2006). Cultural intelligence in global teams. Group and Organization Management, 24-153.

Josefy, M., Dean, T. J., Albert, L. S., \& Fitza, M. A. (2017). The Role of Community in Crowdfunding Success: Evidence on Cultural Attributes in Funding Campaigns to "Save the Local Theater". Entrepreneurship Theory and Practice, 41(2), 161-182.

Kotler, N., \& Kotler, P. (2000). Can Museums be All things to All People?: Missions, Goals, and Marketing's Role. Museum Management and Curatorship, 18(3), 271-287.

Kuppuswamy, V., \& Bayus, B. L. (2015). “Crowdfunding creative ideas: The dynamics of project backers in Kickstarter”, UNC Kenan-Flagler Research Paper, (2013-15).

Leung, A. K.-Y., Maddux, W. W., Galinsky, A. D., \& Chiu, C.-Y. (2008). Multicultural experience enhances creativity: The when and how. American Psychologist, 63(3), 169- 
181. Retrieved from http://ink.library.smu.edu.sg/soss_research/538

Leventhal, J. G., \& Zeylikovich, I. (2015). Relevance and Twenty-First Century Fundraising Fundamentals. In J. Decker (Ed.), Fundraising and Strategic Planning: Innovative Approaches for Museums (pp. 95-102). New York: Rowman \& Littlefield.

Mayer, R. C., Davis, J. H., \& Schoorman, F. D. (1995). An integrative model of organizational trust. Academy of Management Review, 20, 709-734.

McKenny, A. F., Allison, T. H., Ketchen, D. J., Short, J. C., \& Ireland, R. D. (2017). How Should Crowdfunding Research Evolve? A Survey of the Entrepreneurship Theory and Practice Editorial Board. Entrepreneurship Theory and Practice, 41(2), 291-304. http://doi.org/10.1111/etap.12269

Mele, C., Russo-Spena, T., \& Colurcio, M. (2010). Co-creating value innovation through resource integration. International Journal of Quality and Service Science, 2(1), 60-78.

Meyerson, D., Weick, K. E., \& Kramer, R. M. (1996). Swift Trust and Temporary Groups. In R. M. Kramer \& T. R. Tyler (Eds.), Trust in Organizations: Frontries of Theory and Research (pp. 166-195). Thousand Oaks, Calif.: Sage Publications.

Mollick, E. (2014). The dynamics of crowdfunding: An exploratory study. Journal of Business Venturing, 29(1), 1-16. http://doi.org/10.1016/j.jbusvent.2013.06.005

Mollick, E., \& Nanda, R. (2015). Wisdom or Madness? Comparing Crowds with Expert Evaluation in Funding the Arts. Management Science, 1-21. http://doi.org/10.1287/mnsc.2015.2207

Morris, M. H., \& Jones, F. . (1999). Entrepreneurship in established organizations: The case of the public sector. Entrepreneurship Theory and Practice, 24(1), 71-91.

Neck, H. M., \& Corbett, A. C. (2018). The Scholarship of Teaching and Learning Entrepreneurship. Entrepreneurship Education and Pedagogy, 1(1), 8-41.

Ordanini, A., Miceli, L., Pizzetti, M., \& Parasuraman, A. (2011). Crowd-funding: transforming customers into investors through innovative service platforms. Journal of 
Service Management, 22(4), 443-470. Retrieved from

http://dx.doi.org/10.1108/09564231111155079

Peredo, A. M., \& Chrisman, J. J. (2006). Toward a theory of commnity-based enterprise. Academy of Management Review, 31(2), 309-328.

Pickles, M. (2015). How can cultural organisations become more entrepreneurial? Retrieved November 4, 2015, from https://www.weforum.org/agenda/2015/09/how-can-culturalorganisations-become-more-entrepreneurial/

Riley-Huff, D. A., Herrera, K., Ivey, S., \& Harry, T. (2016). Crowdfunding in libraries, archives and museums. The Bottom Line, 29(2), 67-85. http://doi.org/10.1108/BL-032016-0014

Rovner, M., Loeb, P., \& Vogel, G. (2013). The Next generation of American Giving: The Charitable Habits of generation Y, X, Baby Boomers, and Matures. Charleston, SC. Retrieved from file:///C:/Users/mmjon/Downloads/NEXTGENAmericanGiving.pdf

Sanders, M. L. (2012). Theorizing nonprofit organizations as contradictory enterprises: Understanding the inherent tensions of nonprofit marketization. Management Communication Quarterly, 26(1), 179-185. http://doi.org/10.1177/0893318911423761

Schoorman, F. D., Mayer, R. C., \& Davis, J. H. (2007). An integrative model of organizational trust: Past, present, and future. Academy of Management Review, 32(2), $344-354$.

Skirnevskiy, V., Bendig, D., \& Brettel, M. (2017). The influence of internal social capital on serial creators' success in crowdfunding. Entrepreneurship Theory and Practice, 41(2), 209-236.

Thompson, G. (2003). Public Control of Museums in New Zealand and the United Kingdom: Implications for Entrepreneurship. The Journal of Arts Management, Law, and Society, 33(3), 228-239. http://doi.org/10.1080/10632920309597348

Thürridl, C., \& Kamleitner, B. (2016). What Goes Around Comes Around? Rewards as 
Strategic Assets in Crowdfunding. California Management Review, 58(2), 88-110.

Toepler, S. (2006). Caveat venditor? Museum merchandising, nonprofit commercialization, and the case of the Metropolitan Museum in New York. Voluntas: International Journal of Voluntary and Nonprofit Organizations, 17(2), 99-113. http://doi.org/10.1007/s

\section{$11266-006-9012-6$}

Turner, T., \& Gianiodis, P. (2018). Entrepreneurship Unleashed: Understanding Entrepreneurial Education outside of the Business School. Journal of Small Business Management, 56(1), 131-149. http://doi.org/10.1111/jsbm.12365

Wang, C. L., \& Chugh, H. (2014). Entrepreneurial Learning: Past Research and Future Challenges: Advancing Entrepreneurial Learning Research. International Journal of Management Reviews, 16(1), 24-61.

World Bank. (2013). Crowdfunding's Potential for the Developing World. infoDev, Finance and Private Sector Development Department. Washington DC.: World Bank.

Xanthoudaki, M. (2015). Museums, innovative pedagogies and the twenty-first century learner: a question of Methodology. Museum and Society, 13(2), 247-265.

Young, J. E., \& Sexton, D. L. (1997). Entrepreneurial learning: A conceptual framework. Journal of Enterprising Culture, 5(3), 223-248. 